\title{
Speech LeVel Shift in Japanese and Slovene
}

\author{
Jasmina BAJRAMI \\ University of Ljubljana, Slovenia \\ jasmina81@gmail.com
}

\begin{abstract}
In verbal communication, we always aim to establish and maintain harmonious relations with others. Proper use of expressions and the choice of the way we speak are closely connected with politeness. In Japanese speech level is a level of formality or politeness in conversation, which is expressed by the use of linguistic forms (formal vs. informal) within and at the end of an utterance and the use of honorific expressions. In Slovene the level of formality or politeness in conversation is mainly expressed by the use of formal language and general colloquial language. Speech level shift is a shift from one speech level to another - e.g. from a formal style to an informal, etc. According to previous research, these shifts express speaker's psychological distance and a change of attitude towards a hearer. In this paper I will first briefly present the theoretical framework of politeness and an outline of speech levels in Japanese and Slovene. I will then present the data and the method used in this study. Finally, I will present and discuss the results of the analysis of both Japanese and Slovene conversation.
\end{abstract}

Keywords: speech level; speech level shift; politeness; formal style; informal style

\section{Povzetek}

$\checkmark$ govorni komunikaciji vselej stremimo $\mathrm{k}$ vzpostavljanju in ohranjanju skladnih medsebojnih odnosov. Primerna raba izrazov ter izbira načina govora sta tesno povezani $z$ vljudnostjo. $V$ japonskem jeziku stopnja govora pomeni stopnjo formalnosti ali vljudnosti v pogovoru, ki se izraža z jezikovnimi oblikami (formalnimi oz. neformalnimi) znotraj ali na koncu stavka ter s spoštljivimi izrazi. V slovenskem jeziku se stopnja formalnosti ali vljudnosti v pogovoru večinoma izraža $z$ rabo knjižnega jezika in splošnega pogovornega jezika. Menjava stopnje govora je menjava iz ene stopnje govora v drugo $-\mathrm{tj}$. iz formalnega načina govora v neformalnega. Predhodne raziskave kažejo, da takšne menjave stopnje govora odražajo govorčevo psihološko razdaljo in spremembo drže do sogovorca. V članku je najprej na kratko predstavljen teoretični okvir vljudnosti in podan opis stopenj govora $v$ japonskem in slovenskem jeziku. Nato so predstavljeni gradivo in metode, ki so bile uporabljene $v$ tej raziskavi. Na koncu so podani rezultati analize japonskega in slovenskega pogovora.

Ključne besede: stopnja govora; menjava stopnje govora; vljudnost; formalni stil; neformalni stil

Acta Linguistica Asiatica, 6(2), 2016.

ISSN: 2232-3317, http://revije.ff.uni-lj.si/ala/

DOI: 10.4312/ala.6.2.23-51 


\section{Introduction}

Politeness is a linguistic behavior used to ensure the harmony of human relations and plays a crucial role in interpersonal communication.

This paper analyzes the use of speech level and speech level shift in Japanese and Slovene formal conversation from the perspective of Brown and Levinson's (1987) theory of politeness and aims to clarify (1) the conditions which determine the choice of a speech level, (2) the factors that cause speakers to change the speech level, and (3) the kind of functions that these shifts carry in the conversation..

\section{Previous research}

\subsection{Politeness (Brown \& Levinson, 1987)}

Brown and Levinson's theory of politeness is a very prominent early work on politeness among politeness research in pragmatics and in the research of discourse politeness. According to the theory, politeness does not represent courteous manners - it is a linguistic strategy used to establish and maintain harmonious human relations.

The theory is based on the notion of "face", defined as "the public self-image that every member wants to claim for himself", which consists of two related aspects, a negative face and a positive face (Brown \& Levinson, 1987, p. 61). Authors also point out that there are certain kinds of acts that intrinsically threaten the face and call them "facethreatening acts" (FTAs).

The main components of Brown and Levinson's Politeness theory are the notion of "face", formula for estimating the degree of seriousness or weightiness of FTAs, concrete descriptions of politeness strategies, and factors influencing the choice of strategies. According to the theory, politeness strategies are used depending on the weightiness of a face threat (W), which is regulated by three factors (social variables): social distance (D) between speaker and hearer, relative power ( $P$ ) of speaker and hearer, absolute ranking of impositions in the particular culture (R). The greater the face threat, the more polite strategy is used (Brown \& Levinson, 1987, pp. 61-84).

The theory has widely been criticized by numerous scholars from its beginnings. Critics claim that the theory is not appropriate for describing those Asian cultures, in which the use of certain language forms used to express social distance is obligatory. Matsumoto $(1988,1989)$, for instance, believes that Brown and Levinson's claim that politeness strategies are used to mitigate speech acts which threaten face does not apply to Japanese because in Japanese politeness strategies are often used even when there is no face-threatening act. On the other hand, some scholars believe that the theory holds an all-embracing approach and that the concept of negative politeness does apply to Asian languages. Even more, they believe that its universal characteristics can account for a better understanding of a discourse in Japanese (Usami, 2001; 
Pizziconi, 2003). Usami (2002) claims that Brown and Levinson's theory is universal and appropriate for comparisons of politeness systems in different cultures, if it is used at the level on discourse, that is, if we do not focus merely on utterances or sequences of short conversations.

It seems that the common problem of the critique and interpretation of Brown and Levinson's theory from the Japanese language perspective (such as Ide, 1989, and Matsumoto, 1988) lies in the fact, that it seems to only focus on the Japanese honorifics and their analysis, and therefore explanations tend to be overly detailed. In dealing with universality of politeness, it is important to look for common points and characteristics of different languages and not only point out the characteristics and exceptions in Japanese. For this reason, in order to analyze the dynamics of the use of politeness strategies, this study employs Brown and Levinson's theoretical framework and tries to determine, how the three factors - social distance, social power, absolute ranking of imposition - are interrelated and how they influence the use of politeness strategies in disagreements.

\subsection{Previous research in Japanese}

\subsubsection{Speech level shift in Japanese}

In Japanese speech level is a level of formality or politeness in conversation, which is expressed by the use of linguistic forms within and at the end of an utterance: by polite/non-polite copula desu/da and polite/non-polite verb suffix-masu/-dearu within and at the end of an utterance, and by the use of honorific expressions keigo.

Speech level shift in Japanese indicates a shift from formal (desu, -masu) to a plain form (da, -dearu) and vice versa, and a shift from using polite/formal expressions of keigo to using plain expressions and vice versa. The research of speech level shift in Japanese is relatively extensive: Ikuta and Ide (1983), Mimaki (1993, 2001), Usami (1995, 1999, 2001,2002 ) etc. These researchers claim that speech level shift is a discourse strategy used to express speaker's psychological distance and a change of attitude towards the hearer. Moreover, they point out that speech level is influenced by three factors: social context (age, sex, degree of intimacy, educational background, etc.), psychological distance between the speakers and discourse unit (syntactic condition). Their analysis clarify that down shifts (a shift from a polite form to a plain form) as well as up shifts have the purpose of regulating a psychological distance between the speakers. Down shifts are seen mainly when the speaker expresses affection, support or empathy to the hearer. In such cases the shift has the role of shortening the psychological distance between the speakers. On the other hand, the up shifts are seen in more formal situations, for example, when the speaker tries not to invade the hearer's private territory. In such case, by lengthening the psychological distance, the conversation could continue without bumping into an obstacle and without the speaker in some way hurting the hearer. Moreover, the up shift is seen, when the speaker is nervous or there is tension in a conversation. Some of the functions speech level shifts carry in regard to 
a discourse unit are stressing the importance of the topic or content of the conversation and adding an explanation or an example to a previous statement.

\subsubsection{Keigo}

Keigo is a honorific system in Japanese language. It is a special type of honorific speech and polite behavior, determined by relative social status of interlocutors or people who are the subject of the conversation. As a verbal behavior, keigo is a specific linguistic means for expressing the same referential meaning in different ways -i.e. on different levels of respect and politeness.

Keigo is a part of even more extensive system called taigūhyōgen (attitudinal expressions), linguistic expressions which are semantically the same, but differ depending on the addressee, content of the conversation, and different situations. These differences depend on how the speaker sees the addressee (e.g. if the addressee is hierarchically superior to the speaker, speaker will speak with them politely), or how the speaker behaves in certain situations. As a result of this "treatment", in addition to honorific expressions, there are also various expressions of negative meaning, love expressions, etc. ${ }^{1}$ Among all these numerous attitudinal expressions, keigo represents only a part of specific expressions used for expressing respect and politeness.

In describing the characteristics of keigo, Minami (1987) points out koryo (consideration), evaluative attitude (hyōkateki taido) and a proper use of expressions (hyōgen no tsukaiwake). Depending on the subject of the speaker's consideration, Minami points out four different types of consideration. The first one is consideration oriented towards the hierarchical relations; depending on speaker's relationship (superior, subordinate, close, distant, etc.) with the hearer or a third person, the speaker chooses expressions of keigo. The second is consideration to the content of the conversation, where the speaker chooses appropriate expressions according to who or what the content is related to. The third type is consideration to situation, where a speaker chooses their expressions depending on the setting of the conversation. Fourth type is consideration to a medium. This means that the speaker might not use keigo when talking to someone in person, but would use it in a letter to this same person. According to Minami, speaker's evaluative attitude is always accompanied by these four types of consideration. In other words, the speaker will always make a choice of using certain expressions only after putting into consideration who the hearer is, what the setting of the conversation is, what the topic is etc. Moreover, this decision is mainly the result of three standpoints: hierarchical relations, level of closeness, and level of formality of the setting.

In a broad sense we can classify keigo into three main groups: sonkeigo (honorific language), kenjōgo (humble language) and teineigo (polite language). Furthermore, teineigo has a subcategory bikago (refined language).

\footnotetext{
${ }^{1}$ See Kikuchi 1997: p. 29-42 and Minami 1987: p. 12-16.
} 
Sonkeigo is a group of honorific expressions referring to the addressee or the third person, their actions, and all things belonging to them, only when they are superior to the speaker. The speaker expresses respect by using honorific expressions for everything concerning that person or thing, by which he puts them higher than himself.

Kenjōgo is a group of humble expressions, referring to the speaker and speaker's actions, which have some kind of effect on the addressee or the third person (who are superior to the speaker). With kenjoggo the speaker shows respect by humbling himself and his actions, which puts the addressee or the third person above the speaker.

In contrast with the first two groups presented above, teineigo is not used to express respect, but to express formality and politeness of the speaker towards the addressee according to their relationship or the situation. Teineigo is formed with copula desu and a polite verb form masu. Moreover, it can also be formed with copula degozaimasu, which is even more polite than the first two and is usually used in very formal or specific situations (i.e. answering a phone at a work place). Desu is a formal form of the auxiliary verb $d a$ and is attached to nouns and adjectives, whereas masu is a formal form of verbs.

Speaker's choice of the way of speaking, e.g. use/non use of honorific expressions, proper use of the speech level, the use of certain vocabulary, etc., is closely related to Brown and Levinson's politeness theory. According to their theory, in interpersonal communication speakers use politeness strategies in order to preserve harmonious relationships. As mentioned above, Minami (1987) points out that in Japanese the use of keigo depends on human relations (i.e. the level of intimacy and hierarchy), content of the conversation, situation, the setting (formal/informal), etc. For example, the use of formal and informal style in Japanese (teineitai/futsūtai) depends not only on the level of intimacy, but also on the setting or the situation of the conversation. This means that people who are close to each other normally use an informal language in an every-day conversation. However, in a formal setting they would usually use a formal language. Looking from the viewpoint of Brown and Levinson's politeness theory, by using keigo, the speaker is using a negative politeness strategy, intended to satisfy the hearer's negative face. On the other hand, by using an informal language the speaker is attending to the hearer's positive face, which means he is using a positive politeness strategy.

\subsection{Previous research on Slovene}

\subsection{1 "Formal" and "general colloquial" Slovene language}

Toporišič $(1973,2000)$ divides Slovene language into two main categories - social and functional category. Furthermore, he divides the social category into literary language and non-literary language. Non-literary language is the spoken language with various dialects and regional colloquialisms, whereas literary language is the common language everywhere in Slovenia and is further divided into formal language and general colloquial language. 
People who have received at least a secondary education are able to use the formal language. For example, formal language is used by writers, poets, reporters, and others for writing technical and scientific papers, newspaper and magazine articles, official documents etc. Moreover, formal language is used in everyday life as well - for writing journals, letters, emails, etc. It is also used for reading texts written for theater, television, radio, schools, meetings, governmental institutions etc., or speaking when these texts are learned by heart. Originally, formal language is used for writing, however, it is also widely used for speaking. For example, at educational institutions it is spoken by teachers, professors and students, and it is also spoken on television, radio, meetings etc. In other words, when there is some form of an audience, especially when there is a difference in education, dialects or social status between people, it is expected that speakers will use a formal language. Formal language is an old language with entirely determined orthography, pronunciation, accent and literary style and therefore Slovenian speakers know it well. However, its correct use depends mainly on the education and social environment of the speakers.

According to Toporišič $(1973,2000)$, general colloquial language is a freely spoken language, whose rules of grammar and pronunciation are not so rigid. Compared to formal language, general colloquial language differs mostly in pronunciation, however there are differences in functions, syntax and vocabulary. Regarding the pronunciation, perhaps the most obvious difference is the loss of $-i$ at the end of a word in general colloquial language: pisati (to write, formal), pisat (to write, general colloquial). General colloquial language is mainly spoken in informal settings of a smaller number of people, where the social and psychological distance is often smaller, interlocutors can see each other's faces and the conversation is often accompanied by gestures and movements of arms and body. Because all this is especially connected to syntax, syntax of general colloquial language is a little different than the syntax of the formal language. Dialects have a strong influence on general colloquial language, but people, who have received at least secondary education, are able to separate themselves from their dialects and use a language which is closer to the formal language.

The base of formal language as well as general colloquial language is the language, spoken in Slovenian geographical, political and cultural center, the capital Ljubljana. And because in this paper we examine conversation in television debate show, which is a public and formal setting, the formal language and general colloquial language in this debate show is the subject of our analysis.

\subsubsection{Differences between "formal" and "general colloquial" language}

Toporišič (2000) points out the following categories where the most prominent differences are seen between formal language and general colloquial language: pronunciation, vocabulary, the way of writing, accent, linguistic forms, syntax structure. For example, very obvious differences between the two languages are: a) different pronunciation at the end of verb ending in male, singular form: rekel ((he) 
said) is pronounced as rekau in formal language and reku in general colloquial; b) the loss of short infinitive $-i, c)$ difference in accent: nosíti (formal, to carry), nôsit (general colloquial, to carry), etc. Moreover, the pronunciation of general colloquial language is softer compared to the pronunciation of the formal language: short vowels $i \cdot u \cdot a \cdot$ $\partial$ are not pronounced as clearly in general colloquial language.

Another big difference, that we will look at more closely, is a difference in vocabulary. We can say that politeness level in Slovene differs according to the stylistic value of the vocabulary. According to their stylistic value, Toporišič (2000) divides vocabulary into stylistically unmarked words and stylistically marked words. The former are words which express the essential meaning of the word and do not express emotions, time, an origin (foreign) or a dialect, etc. They are used in both formal and general colloquial language, in all settings (formal and casual), and are most commonly known, which is why they are used more frequently than any other words. On the other hand, stylistically marked words are influenced by emotions, time, area, etc. and are therefore mostly used in colloquial language. For example stylistically unmarked word glava (head) is used as such in formal and general colloquial language, whereas its stylistically marked version betica is used in colloquial language and has a negative connotation.

Most words of the general colloquial Slovene language are stylistically unmarked and are frequently used in an everyday and casual conversation, therefore we can say that speakers are very accustomed to using them. This is why we can assume that these words would be commonly used in a formal setting as well. From the politeness point of view we can say that stylistically unmarked words have the highest level of politeness and are used in formal settings, whereas the politeness level, while depending on the type of the word, of stylistically marked words is lower and they are mainly used in a casual and private settings.

Pogorelec (1965) points out that in a formal discussion speakers use the short infinitive (for example, instead of formal morali se bomo zavedati (we must be aware), speakers say moral se bomo zavedat (general colloquial), which is common in colloquial language. Moreover, she found out that the loss of vowels in conjunction words and adverbs is very common. For example, tud (tudi) (also), al (ali) (or), zlo (zelo) (very), etc. According to Pogorelec, the differences in formal and general colloquial language mentioned above depend on the purpose and setting of the conversation. Whether or not someone can properly use formal language in a formal setting depends on their education, environment, social status, etc., therefore it is expected that, due to these factors, some people are not able to properly use formal language and only use general colloquial language or the mixture of the two.

Tivadar (2003) believes that in order to speak on a public television talk show, one must have a good command of formal language and says that the difference in using formal and general colloquial language is connected to the speaker's social and personal characteristics, as well as to their dialect. Moreover, he points out that in such public setting, shifts between a formal and general colloquial language are very frequent. 
All the above researchers share a similar viewpoint regarding characteristics and the use of formal and general colloquial language. Speaker's background and education play an important role in the ability of having a good command of the formal language. Furthermore, according to these studies, differences in pronunciation and vocabulary are the most obvious differences between the formal and general colloquial language.

From all the above mentioned we consider pronunciation and vocabulary to be used deliberately at least to a certain degree, and are the main concern in our analysis about the speech level shift in Slovene.

\section{Methodology}

\subsection{Data}

As data for analysis in this study we used two conversations from two television debate shows - "Sunday Debate" (Nichiyō tōron) for Japanese language and "Friction" (Trenja) for Slovene language. Table 1 shows the basic information about the two shows.

Table 1: Basic data information

\begin{tabular}{|c|c|c|c|}
\hline & Sunday Debate (Nichiyou touron) & \multicolumn{2}{|c|}{ Friction (Trenja) } \\
\hline Time & 60 minutes & \multicolumn{2}{|l|}{60 minutes } \\
\hline $\begin{array}{l}\text { Topic of the } \\
\text { debate }\end{array}$ & $\begin{array}{l}\text { "What are policies regarding } \\
\text { nuclear power plants and nuclear } \\
\text { energy" } \\
\text { 「どうする原発・エネルギ一 } \\
\text { 政策」 } \\
\text { (Dō suru genpatsu enerugii } \\
\text { seisaku) }\end{array}$ & \multicolumn{2}{|c|}{$\begin{array}{l}\text { "Marriage: yes or no?" } \\
\text { ("Poroka: da ali ne?") }\end{array}$} \\
\hline \multirow[t]{3}{*}{ Interlocutors } & Host, male, 53 years old & \multicolumn{2}{|c|}{ Host, male, 39 years old } \\
\hline & Participants: 4 men & \multicolumn{2}{|c|}{12 participants } \\
\hline & $\begin{array}{l}\text { JM01 (47) } \\
\text { JM02 (66) } \\
\text { JM03 (61) } \\
\text { JM04 (43) }\end{array}$ & $\begin{array}{l}7 \text { men: } \\
\text { SM01 (35) } \\
\text { SM02 (34) } \\
\text { SM03 (34) } \\
\text { SM04 (43) } \\
\text { SM05 (36) } \\
\text { SM06 (68) } \\
\text { SM07 (35) }\end{array}$ & $\begin{array}{l}5 \text { women: } \\
\text { SF01 (66) } \\
\text { SF02 (34) } \\
\text { SF03 (45) } \\
\text { SF04 (49) } \\
\text { SF05 (64) }\end{array}$ \\
\hline $\begin{array}{l}\text { Number of } \\
\text { utterances }\end{array}$ & 550 & \multicolumn{2}{|l|}{724} \\
\hline
\end{tabular}




\section{"Sunday Debate" (Nichiyō tōron)}

Sunday Debate is a Sunday morning talk show in Japan broadcasted by national public broadcasting organization NHK. It is in a form of a debate, moderated and run by the host, where usually current political issues, domestic and world state of affairs, are being discussed.

In this particular episode there are five speakers altogether, four guests and a host, all male. The whole debate takes a form of a well moderated calm conversation, without any altercations and explicit conflicts. The verbal exchange is exclusively between the host and other participants; the participants speak only after being asked a question or are being invited to state their opinion by the host. The topic of the show are nuclear power plants - should the government keep them running or should they be shut down. The show was recorded in September 2012, when due to earthquake and nuclear disaster in 2011 the nuclear power plants and nuclear energy were a very hot topic. Regarding the number of running nuclear plants in the future, three scenarios were being discussed in the show: "zero scenario" - as proposed by the government (supported by JM01 and JM04), "15\% scenario" - this means that 15\% of the nuclear power plants would be left running (supported by JM03), and "20-25\% scenario", where $20-25 \%$ of the plants would be left running (supported by JM02).

\section{"Friction" (Trenja)}

Friction was an evening talk show broadcasted on Slovenian commercial television channel POP TV, which dealt with various topics from politics to every-day matters concerning people and their every-day life. Friction had a similar format as Sunday Debate, with a host moderating the show and leading the conversation.

The analyzed episode has 15 participants, both male and female, and a male host. Primarily, the show has a similar course as Sunday Debate, meaning that all interaction is expected to be an exchange between the host and the participants, where the participants should speak only after being given the permission to speak or after being asked a question by the host. However, the speakers soon start to interrupt each other and start speaking without being given the permission to speak. In a few instances the host even intervenes in order to calm the speakers down or to change the topic of conversation in order to prevent further conflict.

The main topic of this show are the possible causes of the fact that Slovenia has the lowest rate of marriages in Europe. Moreover, a big part of the show is also a discussion about same sex marriages and what are the rights of homosexual people regarding marriages and children. Regarding this, there are speakers who think marriage (between a man and a woman) is extremely important, as only such union can provide a proper environment to raise children in. Furthermore, these same speakers are against legalizing same-sex marriages and refuse making them legally equal to heterosexual marriages. Consequently they think two people in same-sex partnerships should not be able to have and raise children, as in their opinion, this is against the 
nature. Such speakers are SM01, SM04, SM07, SF04 and partially SF03. On the other hand, all the other speakers argue that all people, regardless of their sexual orientation, should have same rights and privileges. Most of these speakers also think that getting married will not necessarily ensure a lifelong partnership and that children are the ones that are really important. Moreover, they also think that children can have a good environment and be raised well in any form of the family, as long as they are loved.

Although both shows have a similar format and a similar purpose, i.e. discussing an important topic in order to persuade the audience, the dynamics is quite different. Japanese speakers discuss the topic in a very calm manner and present their opinions in a more subtle way, without any conflict. Whereas Slovene speakers tend to be much more direct, explicit, interruptive and even causing a conflict in a few instances.

\subsection{Data analysis}

\subsubsection{Conversation analysis: Usami (1999): Socio-psycholinguistic Approach}

As a methodology for research on interpersonal communication, Usami (1999) proposes a "Socio-psycholinguistic approach for natural conversation analysis". The approach with an empirical methodology based on quantitative analysis from traditional psychology deals with various social factors such as age of the speakers, their social status, gender, etc. The approach aims to not only explain the discourse structure, but also to clarify the principles of the language use and human behavior through the analysis of conversation as human interaction. Socio-psycholinguistic approach follows specific steps in analyzing the data, and this is also the course taken in this study: after gathering the appropriate data, all the conversations were transcribed based on "Basic Transcription System for Japanese" (see Usami, 1999), which has been developed to suit the approach as a useful tool for explaining human mentality and the mechanism of interpersonal communication. Next was the coding of analyzed items, which were then used for quantitative analysis. Finally, those items which could not be included in the coding process were examined by qualitative analysis.

\subsubsection{Coding items}

\subsubsection{Coding items in Japanese}

In order to examine factors connected with politeness in communication, we first analyzed the conversation on the level of linguistic forms. To do this, we set three types of coding items at the sentence level: speech level at the end of the sentence, speech level of the whole sentence and speech level of the vocabulary. After this, in order to comprehensively understand the relation between speech level and politeness, we looked at speech level shifts from the dynamic side of the discourse level. Table 2 shows coding items for speech level in Japanese and Table 3 shows coding items for speech level shift in Japanese. 
Table 2: Coding items for speech level in Japanese

\begin{tabular}{|l|l|l|l|}
\hline $\begin{array}{l}\text { Coding } \\
\text { items }\end{array}$ & $\begin{array}{l}\text { Speech level at the } \\
\text { end of the sentence }\end{array}$ & $\begin{array}{l}\text { Speech level of the } \\
\text { whole sentence }\end{array}$ & Vocabulary speech level \\
\hline $\begin{array}{l}\text { S: Super- } \\
\text { polite form }\end{array}$ & $/$ & $\begin{array}{l}\text { Utterances which } \\
\text { contain sonkeigo, } \\
\text { kenjōgo, bikago }\end{array}$ & / \\
\hline $\begin{array}{l}\text { P: Polite } \\
\text { form }\end{array}$ & $\begin{array}{l}\text { Sentences which } \\
\text { contain a formal } \\
\text { style of desu/masu }\end{array}$ & $\begin{array}{l}\text { Sentences which } \\
\text { contain a formal } \\
\text { style of desu/masu }\end{array}$ & $\begin{array}{l}\text { Sentences which contain } \\
\text { a honorific title (i.e. } \\
\text { name + san), formal } \\
\text { conjunctions (i.e. ですか } \\
\text { S desukara, because), } \\
\text { etc. }\end{array}$ \\
\hline $\begin{array}{l}\text { N: Non- } \\
\text { polite form }\end{array}$ & $\begin{array}{l}\text { Sentences which } \\
\text { contain an informal } \\
\text { style of da/dearu }\end{array}$ & $\begin{array}{l}\text { Sentences which } \\
\text { contain an informal } \\
\text { style of da/dearu }\end{array}$ & $\begin{array}{l}\text { Sentences which contain } \\
\text { only a name without a } \\
\text { honorific title, sentences } \\
\text { which contain informal } \\
\text { conjunctions (i.e. だから } \\
\text { だけど dakara, } \\
\text { dakedo, because) }\end{array}$ \\
\hline $\begin{array}{l}\text { NM: No- } \\
\text { marker }\end{array}$ & $\begin{array}{l}\text { Sentences without a } \\
\text { marker showing level } \\
\text { of politeness }\end{array}$ & $\begin{array}{l}\text { Sentences without a } \\
\text { marker showing level } \\
\text { of politeness }\end{array}$ & $\begin{array}{l}\text { Sentences without a } \\
\text { marker showing level of } \\
\text { politeness: sentences } \\
\text { which do not contain any } \\
\text { of the markers classified } \\
\text { as "P" and "N" }\end{array}$ \\
\hline
\end{tabular}

Table 3: Coding items for speech level shift in Japanese

\begin{tabular}{|c|c|c|}
\hline \multicolumn{2}{|c|}{ Coding items } & \multirow{2}{*}{$\begin{array}{l}\text { Shift } \\
\text { Shift from interlocutor's preceding utterance: shift from } \\
\text { formal style of desu/masu (P) to informal style of } d a / \text { dearu } \\
\text { (N) }\end{array}$} \\
\hline \multirow{2}{*}{ D } & $\begin{array}{l}\text { DI: Down-shift } \\
\text { from Interlocutor }\end{array}$ & \\
\hline & $\begin{array}{l}\text { DS: Down-shif } \\
\text { from Self }\end{array}$ & $\begin{array}{l}\text { Shift from speaker's own preceding utterance: shift from } \\
\text { formal style of desu/masu (P) to informal style of } d a / \text { dearu } \\
\text { (N) }\end{array}$ \\
\hline \multirow[t]{2}{*}{$U$} & $\begin{array}{l}\text { UI: Up-shift from } \\
\text { Interlocutor }\end{array}$ & $\begin{array}{l}\text { Shift from interlocutor's preceding utterance: shift from } \\
\text { informal style of } d a / \text { dearu }(\mathrm{N}) \text { to formal style of desu/masu } \\
\text { (P) }\end{array}$ \\
\hline & $\begin{array}{l}\text { US: Up-shift from } \\
\text { Self }\end{array}$ & $\begin{array}{l}\text { Shift from own preceding utterance: shift from informal } \\
\text { style of } d a / \text { dearu }(\mathrm{N}) \text { to formal style of desu/masu }(\mathrm{P})\end{array}$ \\
\hline \multirow{2}{*}{ Ns } & $\begin{array}{l}\text { NI: No-shift from } \\
\text { Interlocutor }\end{array}$ & $\begin{array}{l}\text { No shift from interlocutor's preceding utterance (both } \\
\text { utterances contain the same speech level) }\end{array}$ \\
\hline & $\begin{array}{l}\text { NS: No-shift from } \\
\text { Self }\end{array}$ & $\begin{array}{l}\text { No shift from speaker's own preceding utterance (both } \\
\text { utterances contain the same speech level) }\end{array}$ \\
\hline
\end{tabular}




\subsubsection{Coding items in Slovene}

In any language, speech level is determined by the setting of a conversation, relationship between speakers, etc. and according to these factors speakers choose to speak formally or casually. In Slovene these factors are closely related to the use of second person pronouns, pronunciation, vocabulary, etc. As the use of second person pronouns does not usually change throughout the conversation (especially in a formal one), they were not subject of our research. Speech level dynamics in Slovene conversation is best explained by the change in pronunciation and the use of vocabulary, therefore, in order to examine speech level shift in Slovene we have focused on the difference between formal and general colloquial language and analyzed the pronunciation and the use of vocabulary. We have set two coding items for speech level in Slovene: speech level of pronunciation and speech level of vocabulary. Table 4 and Table 5 show speech level and speech level shift coding items in Slovene conversation.

Table 4: Coding items for speech level in Slovene

\begin{tabular}{|l|l|l|}
\hline Coding items & Vocabulary speech level & Pronunciation speech level \\
\hline \hline FL: Formal language & $\begin{array}{l}\text { Sentences which do not } \\
\text { contain any of the words } \\
\text { classified as "GCL", "PT", or } \\
\text { "NT" (sentences which only } \\
\text { contain neutral words of a } \\
\text { formal language) }\end{array}$ & $\begin{array}{l}\text { Sentences which contain a } \\
\text { formal pronunciation }\end{array}$ \\
\hline $\begin{array}{l}\text { GCL: General } \\
\text { colloquial language }\end{array}$ & $\begin{array}{l}\text { Sentences which contain } \\
\text { words of general colloquial } \\
\text { language }\end{array}$ & $\begin{array}{l}\text { Sentences which contain a } \\
\text { pronunciation of general } \\
\text { colloquial language }\end{array}$ \\
\hline PT: Polite title & $\begin{array}{l}\text { Sentences which contain } \\
\text { honorific titles, such as } \\
\text { gospod, gospa (Mr, Mrs) }\end{array}$ & / \\
\hline NT: No polite title & $\begin{array}{l}\text { Sentences which contain } \\
\text { only a name without a } \\
\text { honorific title }\end{array}$ & / \\
\hline $\begin{array}{l}\text { NP: Neutral } \\
\text { pronunciation }\end{array}$ & $/$ & $\begin{array}{l}\text { Sentences where only a } \\
\text { formal pronunciation is } \\
\text { possible }\end{array}$ \\
\hline \hline
\end{tabular}


Table 5: Coding items for speech level shift in Slovene

\begin{tabular}{|c|c|c|}
\hline \multicolumn{2}{|c|}{ Coding items } & Shift \\
\hline \multirow{2}{*}{ D } & $\begin{array}{l}\text { DI: Down-shift } \\
\text { from Interlocutor }\end{array}$ & $\begin{array}{l}\text { Shift from interlocutor's preceding utterance: shift from } \\
\text { formal language (FL) to general colloquial language (GCL) }\end{array}$ \\
\hline & $\begin{array}{l}\text { DS: Down-shift } \\
\text { from Self }\end{array}$ & $\begin{array}{l}\text { Shift from speaker's own preceding utterance: shift from } \\
\text { formal language (FL) to general colloquial language (GCL) }\end{array}$ \\
\hline \multirow{2}{*}{$U$} & $\begin{array}{l}\text { UI: Up-shift from } \\
\text { Interlocutor }\end{array}$ & $\begin{array}{l}\text { Shift from interlocutor's preceding utterance: shift from } \\
\text { general colloquial language }(\mathrm{GCL}) \text { to formal language }(\mathrm{FL})\end{array}$ \\
\hline & $\begin{array}{l}\text { US: Up-shift from } \\
\text { Self }\end{array}$ & $\begin{array}{l}\text { Shift from speaker's own preceding utterance: shift from } \\
\text { general colloquial language }(G C L) \text { to formal language ( } F L)\end{array}$ \\
\hline \multirow{2}{*}{ Ns } & $\begin{array}{l}\text { NI: No-shift from } \\
\text { Interlocutor }\end{array}$ & No shift from interlocutor's preceding utterance \\
\hline & $\begin{array}{l}\text { NS: No-shift from } \\
\text { Self }\end{array}$ & No shift from speaker's own preceding utterance \\
\hline
\end{tabular}

\section{Results of analysis and discussion}

\subsection{Basic information about the data}

Basic information about the Japanese and Slovene data is presented in Tables 6 and 7.

Table 6: Basic information about the conversation data

\begin{tabular}{|c|c|c|c|}
\hline \multirow[b]{2}{*}{ Language } & \multirow[b]{2}{*}{$\begin{array}{l}\text { Duration of } \\
\text { conversation }\end{array}$} & \multicolumn{2}{|c|}{ Number of utterances } \\
\hline & & $\begin{array}{l}\text { Number of all } \\
\text { utterances }\end{array}$ & $\begin{array}{c}\text { Number of utterances, } \\
\text { which were subject of } \\
\text { analysis }^{2}\end{array}$ \\
\hline Japanese & 60 minutes & 550 & 542 \\
\hline Slovene & 60 minutes & 724 & 722 \\
\hline
\end{tabular}

Table 7: Basic information about the speakers

\begin{tabular}{||l|l||}
\hline \multicolumn{2}{|c|}{ Speaker (age): profession } \\
\hline Japanese & Slovenian \\
\hline Host (53) & Host (39) \\
\hline $\begin{array}{l}\text { JM01 (47): Minister of State for } \\
\text { National Policy (0\% scenario) }\end{array}$ & SM01 (35): priest \\
\hline
\end{tabular}

\footnotetext{
${ }^{2}$ Utterances, which do not contain any of the coding items and utterances, which were not possible to entirely transcribe (due to an indistinct sound or pronunciation), were not a subject of analysis.
} 


\begin{tabular}{|c|c|}
\hline \multicolumn{2}{|c|}{ Speaker (age): profession } \\
\hline Japanese & Slovenian \\
\hline $\begin{array}{l}\text { JM02 (66): specially appointed } \\
\text { professor at Tokyo Institute of } \\
\text { Technology (20-25\% scenario) }\end{array}$ & SM02 (34): actor \\
\hline $\begin{array}{l}\text { JM03 (61): professor at Graduate } \\
\text { school of Hitotsubashi University } \\
\text { (15\% scenario) }\end{array}$ & $\begin{array}{l}\text { SM03 (34): journalist, human rights } \\
\text { activist }\end{array}$ \\
\hline \multirow{4}{*}{$\begin{array}{l}\text { JM04 (43): senior researcher at } \\
\text { Fujitsu Research Institute } \\
\text { 0\% scenario }\end{array}$} & SM04 (43): priest \\
\hline & SM05 (36): athlete \\
\hline & SM06 (68): jurisconsult, journalist \\
\hline & $\begin{array}{l}\text { SM07 (35): high school teacher, } \\
\text { family therapist }\end{array}$ \\
\hline \multirow{5}{*}{ / } & SF01 (66): actress \\
\hline & SF02 (34): athlete \\
\hline & SF03 (45): psychologist, singer \\
\hline & SF04 (49): politician \\
\hline & SF05 (64): singer \\
\hline
\end{tabular}

As we can see in Table 6, out of 550 utterances produced in Japanese conversation, 542 utterances were a subject of analysis. This means that the sentences which did not include any of the coding items or which were not possible to be transcribed entirely (due to an indistinct sound or pronunciation) were not analyzed. In the Slovene conversation there were 724 utterances produced, of which 722 were analyzed.

Table 8 below shows frequencies and percentages of all utterances for every speaker.

Table 8: Frequency and the percentage of all utterances for every speaker in Japanese and Slovene

\begin{tabular}{||c|c|c|c|c|c||}
\hline \multicolumn{3}{|c|}{ Japanese } & \multicolumn{3}{c||}{ Slovene } \\
\hline Speaker & $\begin{array}{c}\text { No. of } \\
\text { Utterances }\end{array}$ & $\begin{array}{c}\text { Percentage } \\
\text { (\%) }\end{array}$ & Speaker & $\begin{array}{c}\text { No. of } \\
\text { Utterances }\end{array}$ & $\begin{array}{c}\text { Percentage } \\
\text { (\%) }\end{array}$ \\
\hline \hline Host & 144 & 26,2 & Host & 140 & 19,3 \\
\hline JM01 & 127 & 23,1 & SM01 & 31 & 4,3 \\
\hline JM02 & 106 & 19,2 & SM02 & 75 & 10,4 \\
\hline JM03 & 102 & 18,6 & SM03 & 130 & 17,9 \\
\hline JM04 & 71 & 12,9 & SM04 & 45 & 6,2 \\
\hline & & & SM05 & 18 & 2,5 \\
\hline
\end{tabular}




\begin{tabular}{||c|c|c|c|c|c||}
\hline \multicolumn{3}{|c|}{ Japanese } & \multicolumn{3}{c|}{ Slovene } \\
\hline Speaker & $\begin{array}{c}\text { No. of } \\
\text { Utterances }\end{array}$ & $\begin{array}{c}\text { Percentage } \\
(\%)\end{array}$ & Speaker & $\begin{array}{c}\text { No. of } \\
\text { Utterances }\end{array}$ & $\begin{array}{c}\text { Percentage } \\
\text { (\%) }\end{array}$ \\
\hline \hline & & & SM06 & 38 & 5,2 \\
\hline & & & SM07 & 17 & 2,4 \\
\hline & & & SF01 & 47 & 6,5 \\
\hline & & & SF02 & 14 & 1,9 \\
\hline & & & SF03 & 73 & 10,1 \\
\hline & & & SF04 & 71 & 9,8 \\
\hline Total & $\mathbf{5 5 0}$ & $\mathbf{1 0 0 , 0}$ & Total & $\mathbf{7 2 4}$ & $\mathbf{1 0 0 , 0}$ \\
\hline
\end{tabular}

As we can see from the table above, the highest number of utterances in both languages belongs to the host, with the Japanese host taking up $26,2 \%$ of all utterances in Japanese conversation, and the Slovenian host taking up 19,3\% of all utterances in Slovenian conversation. We can say that these highest percentages in both languages, as Komiya (1991) has pointed out, are due to the fact that the discussion is taking place under the guidance of the host. In other words, the speakers normally speak only after being given the permission or asked a question by the host. It is important to know how much a certain speaker speaks, as this consequently effects the number of shifts of each speaker - if the speaker produces more utterances, he has more opportunities to switch between speech levels.

\subsection{Japanese language: results of analysis and discussion}

In analyzing Japanese conversation, we have analyzed every speech level (speech level at the end of the sentence, speech level of the whole sentence and vocabulary speech level) from four different point of views: a) the use of each speech level in regard to the number of all utterances in the conversation, b) the use of each speech level in regard to all utterances for every individual speaker, $c$ ) the use of each speech level only in utterances with politeness markers (utterances classified as S, P and N), d) the use of each speech level only in utterances with politeness markers for every individual speaker. Furthermore, we have looked at the speech level shift from the global (quantitative analysis) and local (qualitative analysis) point of view. Some of the main findings are presented below. 


\subsubsection{Speech level in Japanese}

\subsubsection{Speech level at the end of the sentence in Japanese}

Figure 1 below presents the use of each speech level at the end of the sentence for each individual speaker in Japanese.

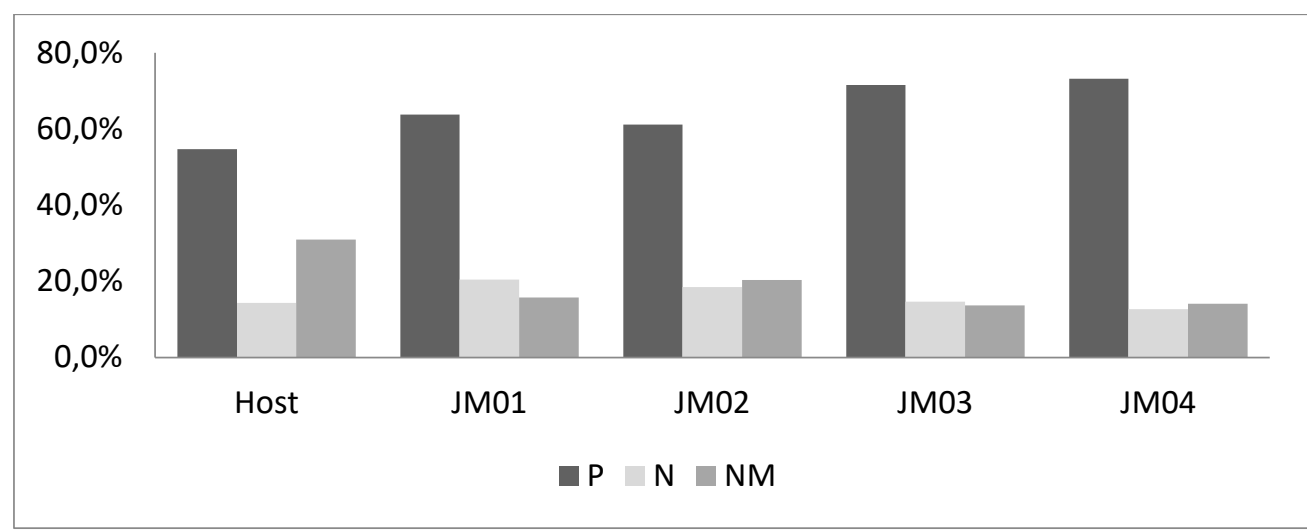

Legend: $\mathrm{P}=$ polite; $\mathrm{N}=$ non-polite; $\mathrm{NM}=$ no-marker

Figure 1: The use of each speech level by individual speakers

As we can see from Figure 1, formal style is most commonly used among all the speakers, which we can say is appropriate use of the speech level in a formal setting, while the use of informal style and utterances without politeness markers was not as frequent. If we take a look at all the participants (JM01, JM02, JM03, JM04), we can see that there is not much difference in speech level use between them. However, looking at the host, we can notice that he produced a rather high number of utterances without politeness markers. According to Usami (2001), the use of utterances without politeness markers functions as a strategy for avoiding acknowledgement of hierarchical relationship between the speaker and the addressee. When the host is speaking to all four participants he often uses utterances without politeness markers in order to stay neutral, however, when he addresses each participant respectively, he uses tends to use a formal style.

\subsubsection{Speech level of the whole sentence in Japanese}

To see the use of the speech level of the whole sentence in Japanese, in addition to the use of formal and informal style within the utterance, we have also looked at the use of keigo which we have labeled as "S" (super polite). Figure 2 presents the use of speech level of the whole sentence for each individual speaker. 


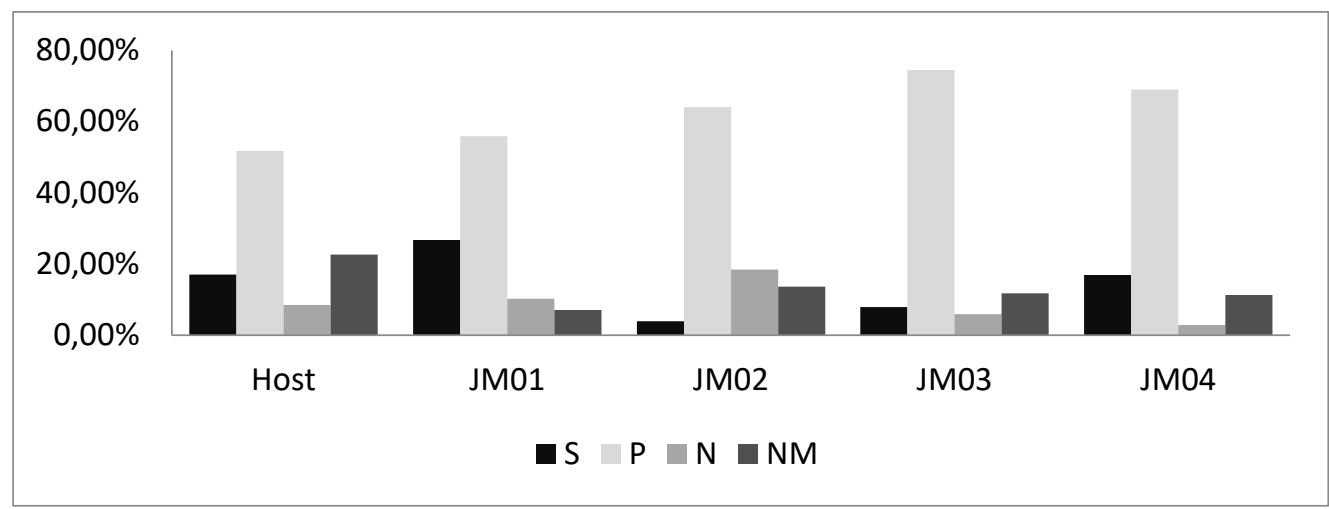

Legend: $\mathrm{S}=$ super polite; $\mathrm{P}=$ polite; $\mathrm{N}$ = non-polite; $\mathrm{NM}=$ no-marker

Figure 2: The use of each speech level of the whole sentence by individual speakers

From Figure 2 we can see that the use of the polite form (formal style) is the most frequent among all the speakers, which is a basic speech level for a formal setting such as a television talk show. A fact which should be pointed out is the use of keigo (S), which is relatively low. The reason for this is perhaps in the course of the conversation. Keigo is known to be mostly used to express the relations between the speakers, however, this conversation is not the kind of setting where speakers would be addressing each other as most of the interaction is between a host and a participant (participants do not speak directly to each other). Moreover, the topic of the conversation are not of a personal matter and experience, but rather of a more general nature (issues in the country), which may also be considered as a reason for such a low use of keigo.

\subsubsection{Speech level of the vocabulary in Japanese}

Figure 3 presents the use of the vocabulary speech level in Japanese, for each speaker individually.

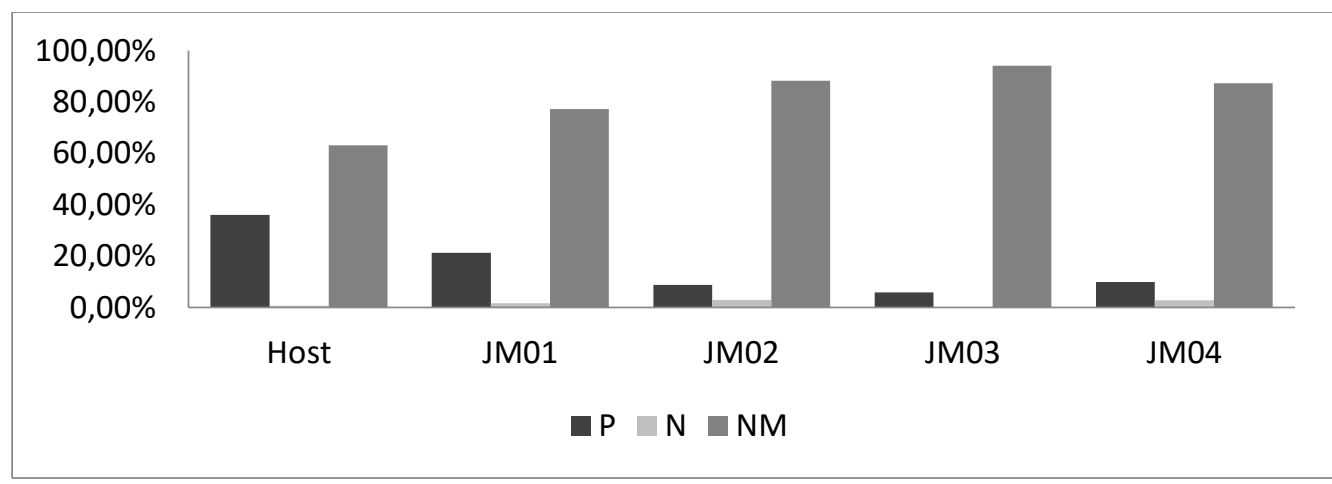

Legend: $\mathrm{P}=$ polite; $\mathrm{N}=$ non-polite; $\mathrm{NM}=$ no-marker

Figure 3: The use of the vocabulary speech level in Japanese by individual speakers 
As we can see from Figure 3 , the host uses polite vocabulary (i.e. polite titles) most frequently as he is the one mostly addresses of all the participants. Moreover, we can see that the use of non-polite vocabulary is very low, and all of the non-polite use was limited to the plain form of conjunction word dakara, dakedo, meaning there was no occurence of a non-use of polite titles.

\subsubsection{Speech level shift in Japanese}

In Japanese, speech level shift is the shift of a speech level at the end of a sentence. Analyzing speech level shifts will allow us to better understand the function of different elements related to politeness. As the speech level shift is a dynamic phenomenon within the conversation, we have looked at it from the global and local point of view. At the global level we have looked at the frequency of speech level shifts in all utterances of the conversation and at the frequency of speech level shifts by individual speakers. At the local level we have looked at the factors influencing the occurrence of the shifts and the functions that these shifts carry in the conversation.

\subsubsection{Analysis of the speech level shifts from the global point of view}

Figure 4 presents the use of speech level shifts by individual speakers.

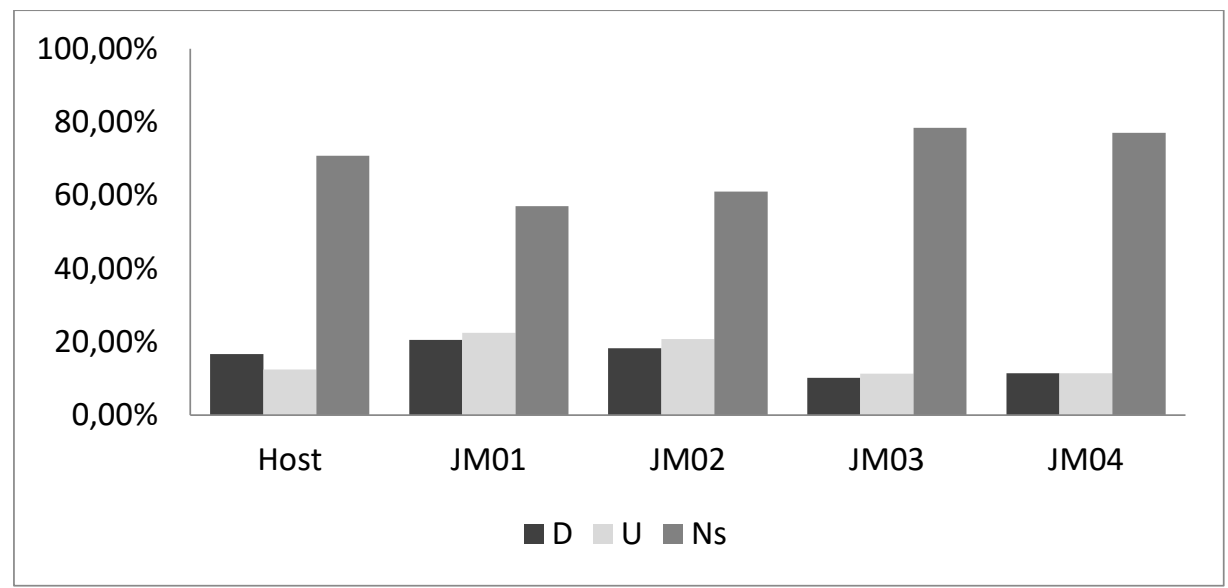

D: down shift; U; up shift; Ns: no shift

Figure 4: The use of speech level shifts by individual speakers

If we take a look at the Figure 4, we can see that the use of Ns (no shift) was the highest, while the use of $D$ (down shift) and $U$ (up shift) was almost the same among all speakers. We can explain these results if we take into consideration the fact that the use of a formal style (P), which is the basic speech level in this conversation, was the highest among all the speakers and the use of informal style $(\mathrm{N})$ was very low. This means that all the speakers tend to preserve the basic speech level $(P)$ and therefore very rarely conduct the shifts. When they do shift from a formal to informal style, they 
soon shift back up to the formal style - hence the relatively same use of up and down shifts.

\subsubsection{Analysis of the speech level shifts from the local point of view}

By analyzing the shifts from the local point of view, we are able to see what kind functions these shifts carry in the conversation. Because the conversation in a television talk show is of a formal nature, the number of shifts which carry the function of regulating the psychological distance between the speakers is very small. On the other hand, the number of shifts carrying the functions connected with the development of the discourse, is relatively high. Some of these shifts had the following functions: further clarifying the preceding utterance, pointing out or stressing the importance of the conversation content, preserving the basic speech level, changing the topic of conversation, etc.

According to Usami (1995), up-shift in a formal conversation is often conducted due to a sudden and temporary down-shift in order to return and preserve the polite level considered as appropriate (and basic) in such situation.

Below is an example of two shifts: the first one carries a function of explaining the previous utterance and the second one has the function of returning to a basic (polite) speech level.

Example (1)

\begin{tabular}{|c|c|c|c|c|c|}
\hline Line & Speaker & Conversation content & SL & Shift & $\mathbf{F}$ \\
\hline 1 & JM01 & $\begin{array}{l}\text { ですから、やはり、大事なことは政府として大き } \\
\text { な方向性というものをですね、やはり共有してい } \\
\text { く、でしかも私たちが作っていこうとして新しい } \\
\text { エネルギ一社会は、国民の皆さん一人一人の参加 } \\
\text { が必要なんです。 } \\
\text { Desukara, yahari, daijina koto wa seifu toshite ōkina } \\
\text { hōkōsei toiu mono wo desune, yahari kyōyūshiteiku, de } \\
\text { shikamo watashitachi ga tsukutteikō toshite atarashii } \\
\text { enerugii shakai wa, kokumin no minasan hitori hitori no } \\
\text { sanka ga hitsuyōnandesu. } \\
\text { Therefore, of course it is important that we share this } \\
\text { great course with government and we must all } \\
\text { participate in creating a new energy-efficient society. }\end{array}$ & $P$ & NS & \\
\hline
\end{tabular}




\begin{tabular}{|c|c|c|c|c|c|}
\hline 2 & JM01 & $\begin{array}{l}\text { あの、これまでのょうに、あの電力会社がですね } \\
\text { 、集中的に大きな電力を作って供給するという仕 } \\
\text { 組みから、一人一が電気を作ったり、節約した } \\
\text { りという、そいう分散ネットワーク型のエネルギ } \\
\text { 一社会にしていく。 } \\
\text { Ano, koremadenoyōni, ano denryoku kaisha desune, } \\
\text { shūchūtekini ókina denryoku wo tsukutte kyōkyūsuru } \\
\text { toiu shikumi kara, hitori hitori ga denki wo tsukuttari, } \\
\text { setsuyakushitari toiu, sōiu bunsan nettowaakukata no } \\
\text { enerugii shakainishiteiku. } \\
\text { Well, until now power companies have been creating } \\
\text { and supplying us with a great amount of electric power } \\
\text { and now we must change this by saving and so creating } \\
\text { a dispersed network of energy-efficient society. }\end{array}$ & $\mathrm{N}$ & DS & 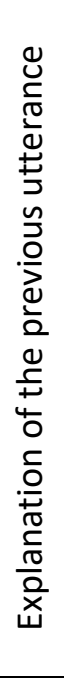 \\
\hline 3 & JM01 & $\begin{array}{l}\text { ま、そのために国民の皆さん方の協力が必要で、 } \\
\text { そういうやっばり国民の皆がですね、意識を共有 } \\
\text { してやっていく、ま、そういう意味では大きな方 } \\
\text { 向性を示すということは非常に大事なことだとい } \\
\text { うふうに思っています。 } \\
\text { Ma, sonotameni kokumin no minasangata no kyōryoku } \\
\text { ga hitsuyōde, sōiu yappari kokumin no minna ga } \\
\text { desune, ishiki wo kyōyūshiteyatteiku, ma, sōiu imi de } \\
\text { wa ōkina hōkōsei wo shimesu toiu koto wa hijōni } \\
\text { daijina kotoda toiufūni omotteimasu. } \\
\text { Well, for this all the people's cooperation is needed, } \\
\text { everyone should be aware, well, I think in this sense it's } \\
\text { important to follow the same great course. }\end{array}$ & $P$ & US & 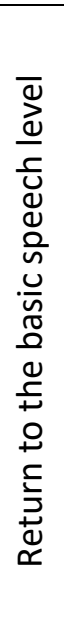 \\
\hline \multicolumn{6}{|c|}{$\begin{array}{l}\text { Legend: } \\
\text { SL: Speech level at the end of the sentence } \\
\text { F: Factors influencing the occurrence of shifts }\end{array}$} \\
\hline
\end{tabular}

In this example JM01 is using a formal style in presenting his opinion, but in line 2 he suddenly conducts a down-shift to an informal style in order to give a further explanation. Then in line 3 he shifts back to the formal style in order to return to the basic level of the conversation.

Moreover, we have found out that when speakers conducted a shift, they conducted an up-shift to the formal style to assert themselves (speak about their own opinion) and a down-shift to explaining or point out general matters. Example (1) above shows these shifts: in line $2 \mathrm{JM} 01$ explains something of a general knowledge and therefore conducts a down-shift. After this in line 3 he expresses his own opinion (asserts himself) and to do so he conducts an up-shift to a formal level. 
Looking at this from Brown and Levinson's politeness theory point of view, when a speaker uses a formal desu/masu style, they show that they do not want to interfere with the hearer's personal space. In such case, according to the politeness theory, the speaker is expressing a negative politeness. An act of expressing one's own opinion is considered to be more face threatening than presenting general matters, because there is a possibility that a hearer will not share the same opinion with a speaker, and speaker's opinion may consequesntly be perceived as imposing. Therefore in order not to cause any damage to a hearer's negative face, a speaker uses formal style when expressing their own opinion.

\subsection{Results of analysis and discussion in Slovene language}

\subsubsection{Speech level in Slovene}

To look at the speech level in Slovene, we have analyzed the speech level of the vocabulary and pronunciation.

\subsubsection{Speech level of the vocabulary in Slovene}

Figure 5 below presents the use of speech level of the vocabulary for each individual speaker in Slovene.

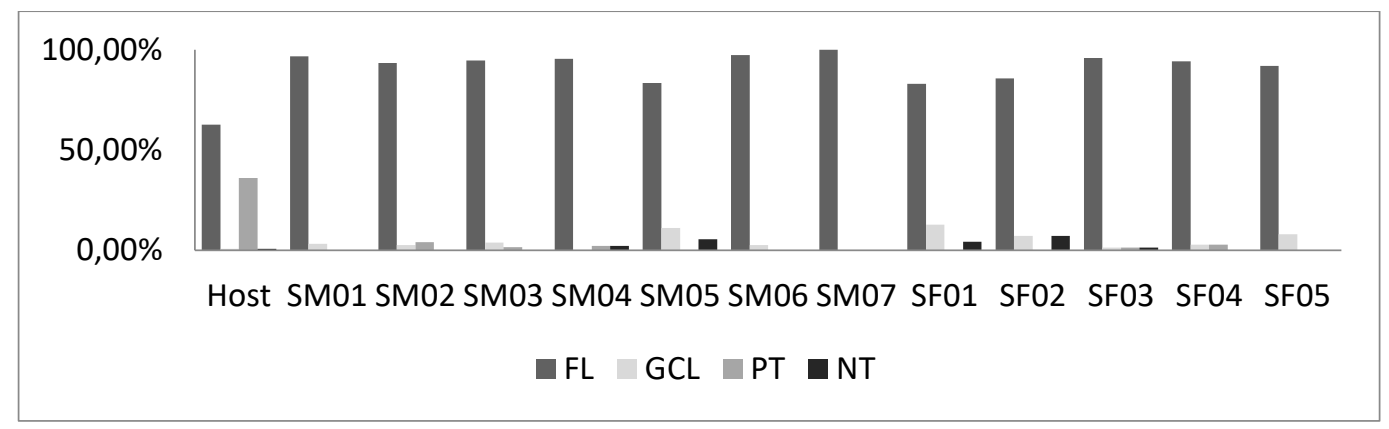

FL: formal language; GCL: general colloquial language; PT: polite title; NT: no polite title

Figure 5: The use of the speech level of the vocabulary in Slovene by individual speakers

Looking at the results of speech level of the vocabulary, the frequency of formal language words (FL) is the highest. Such results were expected, because - as we have said before - most words in Slovene are formal or neutral (unmarked). Furthermore, we can see that the use of the general colloquial language $(\mathrm{GCL})$ words is very rare, which means that most speakers choose the level of vocabulary according to the formal setting of a conversation. The use of the few GCL words may thus be attributed to the speaker's character and background. In other words, someone who frequently uses formal language in their everyday life (i.e. people with professions, where they are expected to use a formal language: politicians, professors, etc.) will most likely use it in a formal setting, such as a television talk show, as well. People who do not use formal language as much in their private lives due to the nature of their profession and other 
social background, will, on the other hand, tend to use GCL words more frequently. For example, if we take a look at SM07: he only used the vocabulary of the formal language, which may be due to the fact that he is a teacher and is therefore used to using a formal language in his everyday life.

\subsubsection{Speech level of the pronunciation in Slovene}

We have looked at the use of pronunciation (formal or general colloquial) of words, which reflects the speaker's perception of a linguistic behavior and the situation of a conversation. Figure 6 presents the use of pronunciation by individual speakers.

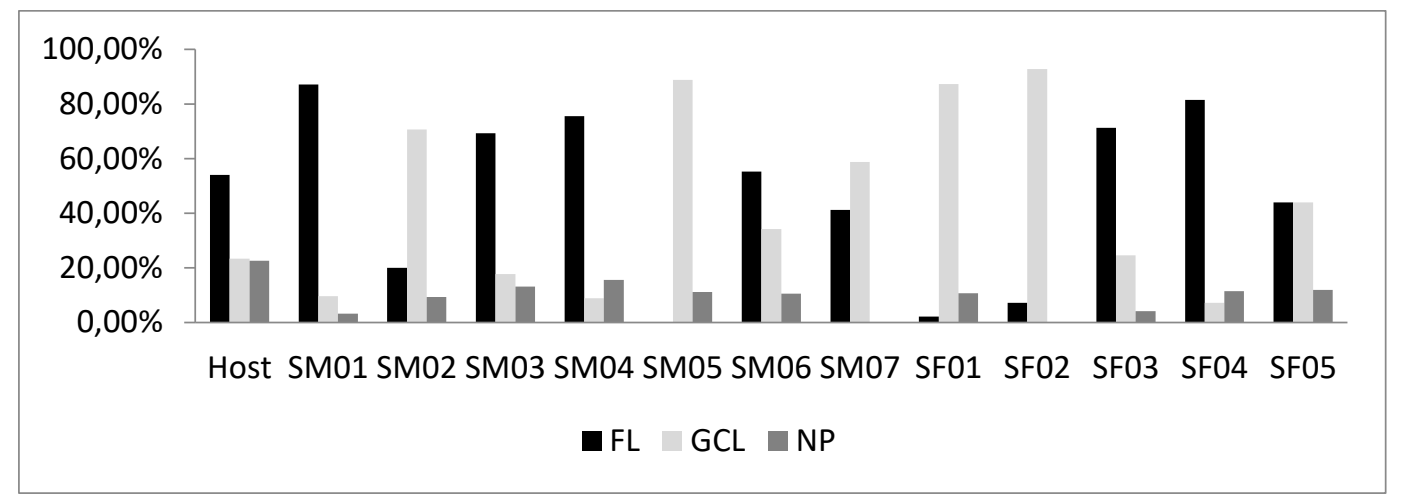

FL: formal language; GCL: general colloquial language; NP: neutral pronunciation

Figure 6: The use of pronunciation by individual speakers in Slovene

As we can see from the Figure 6 , the use of formal and general colloquial pronunciation varies greatly. While this is also due to the difference in the number of utterances by individual speakers, it is, even more importantly, also due to the factors like speaker's character and background. As we have seen with the use of vocabulary, the use of pronunciation depends on whether the speaker uses formal language in his everyday life or not - it therefore depends on the speaker's profession, education, life style, etc. For example, speakers SM01 (priest), SM03 (journalist), SM04 (priest), SM06 (jurisconsult, publicist), SF03 (psychologist), SF04 (politician) all use the formal pronunciation much more than the general colloquial, which may be attributed to their professions.

\subsubsection{Speech level shift in Slovene}

Speech level shift in Slovene is a shift in the level of pronunciation. For example, a change from using formal pronunciation, such as delati, videl, žal (work, saw, unfortunately), to using a general colloquial pronunciation, such as delat, vidu, žou, was considered a down-shift. 
Same as in Japanese, speech level shift in Slovene was also analyzed from the global and local point of view.

\subsubsection{Analysis of the speech level shifts from the global point of view}

Figure 7 presents the use of speech level shifts by individual speakers.

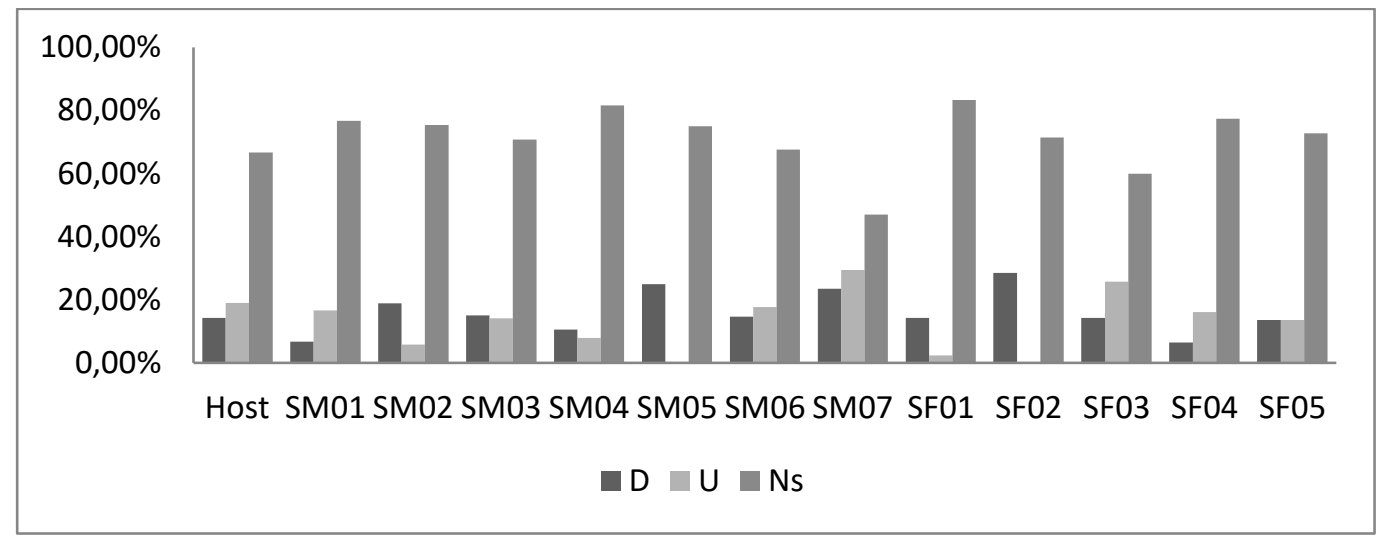

D: down shift; U: up shift; Ns: no shift

Figure 7: The use of speech level shifts by individual speakers in Slovene

Results of the analysis of the use of speech level shifts show that all speakers tend not to shift speech levels. If we compare these results with the results of the use of pronunciation speech level we can see that most of the speakers, who generally use formal pronunciation (host, SM01, SM06, SF03, SF04), conduct more up-shifts than down-shifts. The reason for it is that they want to preserve the formal speech level, which is the basic speech level of the conversation. This means that when they suddenly conduct a down-shift by using a general colloquial pronunciation, or when the preceding speaker uses a general colloquial pronunciation, they perceive this as a deviation from the basic speech level and in order to preserve it, the conduct an upshift (from GCL to FL).

\subsubsection{Analysis of the speech level shifts from the local point of view}

Analyzing the shifts from the local point of view we have found that most shifts carry the function of developing the discourse, among which more than half of shifts occurred when speakers continued to further explain the preceding utterance, and approximately $16 \%$ of shift occurred when the speaker changed the topic.

The example below shows speech level shifts carrying the function of presenting a new topic and further explaining the preceding utterance. 
Example (2)

\begin{tabular}{|c|c|c|c|c|c|}
\hline Line & Speaker & Conversation content & SL & Shift & $F$ \\
\hline 1 & SM04 & $\begin{array}{l}\text { Potem pa gospodu }{ }_{\mathrm{SM}} \mathrm{S} /(\mathrm{mhm}) \text {, replika. } \\
\text { And then a reply to } \mathrm{SM} 03 .\end{array}$ & FL & NS & \\
\hline 2 & SM04 & $\begin{array}{l}\text { Seveda, a, cerkev ni vedno imela, e, zakonske pastorale } \\
\text { tako visoko kot jo ima danes - danes ima zelo visoke } \\
\text { standarde. } \\
\text { Of course, the church's pastoral of the marriage hasn't } \\
\text { always been as high as it is today - today it has high } \\
\text { standards. }\end{array}$ & FL & NS & \\
\hline 3 & SM04 & $\begin{array}{l}\text { V srednjem veku vemo, da je to področje blo precej } \\
\text { razpuščeno, ne. } \\
\text { In the Middle Ages this field was quite unregulated. }\end{array}$ & $\mathrm{GCL}$ & DS & $\begin{array}{l}\frac{0}{2} \\
0 \\
\frac{1}{3} \\
2\end{array}$ \\
\hline 4 & SM04 & $\begin{array}{l}\text { Poroka se je začela uveljavljati pravzaprav z novim } \\
\text { vekom pa ta, to insistiranje na, na zakonskem življenju. } \\
\text { Marriage and married life actually started to gain } \\
\text { importance with the Modern history. }\end{array}$ & $\mathrm{FL}$ & US & 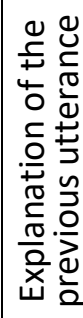 \\
\hline \multicolumn{6}{|c|}{$\begin{array}{l}\text { Legend: } \\
\text { SL: Speech level at the end of the sentence } \\
\text { F: Factors influencing the occurrence of shifts }\end{array}$} \\
\hline
\end{tabular}

Before the example presented above, SM04 was talking about the importance of marriage as a ritual, and then in line 1 he said he wanted to add a reply to SM03. First in line 2 he said that the pastoral of marriage was very important (similar to what he discussed earlier in the conversation), but then explained that it had not always been so. In line 3 he then started a new topic - the historical background of the marriage, and conducted a down-shift. Then in line 4 he shifted back to the formal speech level in order to explain his preceding utterance and at the same time returned back to the basic (formal) speech level. 


\subsection{Comparison of the speech level shifts in Japanese and Slovene}

Figure 8 presents the total use of speech level shifts in Japanese and Slovene.
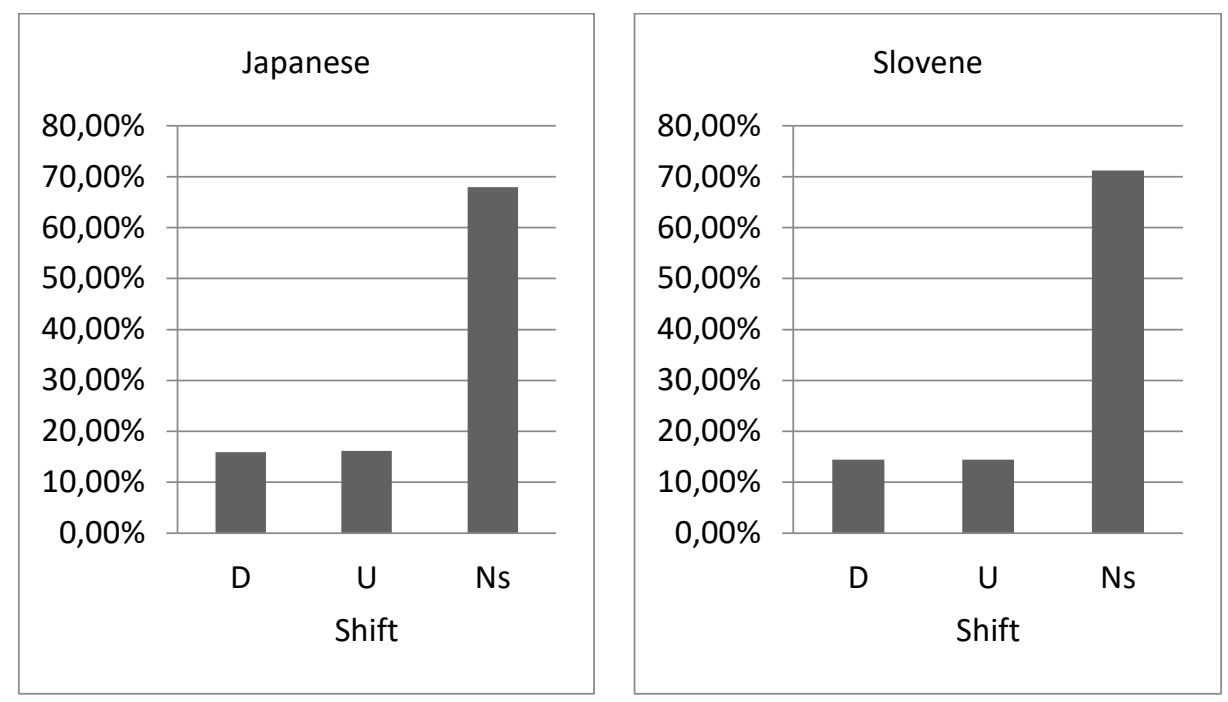

Figure 8: The use of speech level shifts in Japanese and Slovene

The frequency of the use of shifts ( $D=$ down, $U=$ up or Ns=no-shift) was very similar in both languages: in both languages the use of down and up-shifts respectively was only around $15 \%$, which means that no-shifts amounted to around $70 \%$. This shows that in both languages speakers tend to preserve the basic speech level (the speech level that is expected to be used in a certain conversation) and that speakers usually shift back to the speech level they mostly use in this conversation (this also means that, for example, the Slovene speaker, who mostly uses the general colloquial pronunciation shifts down from the formal pronunciation, if the preceding speaker was using the formal speech level). Another reason why there are so many no-shifts in these two conversations is the formal setting of the conversation. Namely, according to the previous research of the speech level shift in Japanese, the shifts often occur due to the regulation of the psychological distance between the speakers. But because this setting is not the type of setting where human relations are being formed, the use of no-shifts is the highest.

Furthermore, we have conducted a local analysis in order to see what kind of functions the shifts in both languages carry in the conversation. Table 9 shows the percentage of shifts carrying different functions in Japanese and Slovene. 
Table 9: Percentage of shifts carrying different functions in Japanese and Slovene

\begin{tabular}{|c|c|c|c|c|c|c|}
\hline & \multirow{2}{*}{ Factors causing the shift } & \multirow{2}{*}{ Function of the shift } & \multicolumn{2}{|c|}{ Japanese } & \multicolumn{2}{|c|}{ Slovene } \\
\hline & & & D & $\mathbf{U}$ & D & $\mathbf{U}$ \\
\hline \multirow{3}{*}{ 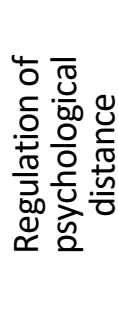 } & $\begin{array}{l}\text { Expressing empathy to the } \\
\text { addressee }\end{array}$ & $\begin{array}{l}\text { Shortening of the } \\
\text { psychological distance }\end{array}$ & 1,5 & 0,0 & 0,0 & 0,0 \\
\hline & Joking & $\begin{array}{l}\text { Shortening of the } \\
\text { psychological distance }\end{array}$ & 0,0 & 0,0 & 1,1 & 1,1 \\
\hline & $\begin{array}{l}\text { Matching the addressee's } \\
\text { level }\end{array}$ & $\begin{array}{l}\text { Shortening of the } \\
\text { psychological distance }\end{array}$ & 0,0 & 1,4 & 0,0 & 0,0 \\
\hline \multirow{9}{*}{ 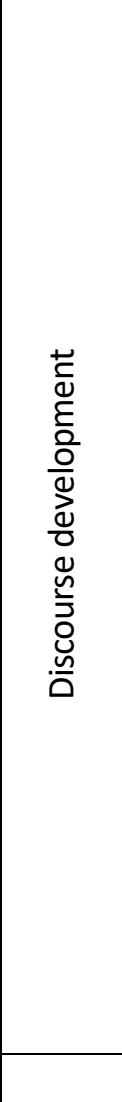 } & $\begin{array}{l}\text { Returning to the basic } \\
\text { speech level }\end{array}$ & $\begin{array}{l}\text { Preserving the basic } \\
\text { speech level }\end{array}$ & 0,0 & 28,2 & 0,0 & 0,0 \\
\hline & $\begin{array}{l}\text { Moving on to the new } \\
\text { topic }\end{array}$ & $\begin{array}{l}\text { Indicating the change of } \\
\text { the topic }\end{array}$ & 7,3 & 2,8 & 15,4 & 15,4 \\
\hline & $\begin{array}{l}\text { Explaining, giving an } \\
\text { example, supplementing } \\
\text { preceding utterance }\end{array}$ & $\begin{array}{l}\text { Clarifying the preceding } \\
\text { utterance }\end{array}$ & 50,0 & 25,3 & 59,3 & 51,6 \\
\hline & $\begin{array}{l}\text { Expressing or emphasizing } \\
\text { the conclusion, intention, } \\
\text { fact, argument, etc. }\end{array}$ & $\begin{array}{l}\text { Pointing out the } \\
\text { importance of the } \\
\text { conversation content }\end{array}$ & 29,4 & 32,4 & 5,5 & 5,5 \\
\hline & $\begin{array}{l}\text { Question-answer session } \\
\text { in order to confirm } \\
\text { something }\end{array}$ & $\begin{array}{l}\text { Deepening the } \\
\text { understanding of the } \\
\text { conversation/utterance } \\
\text { content }\end{array}$ & 4,4 & 4,2 & 2,2 & 7,7 \\
\hline & $\begin{array}{l}\text { Asking a question, } \\
\text { requesting a comment or } \\
\text { information }\end{array}$ & $\begin{array}{l}\text { Deepening the } \\
\text { understanding of another } \\
\text { speaker's opinion }\end{array}$ & 7,3 & 5,6 & 5,5 & 5,5 \\
\hline & $\begin{array}{l}\text { Requesting a right to } \\
\text { speak }\end{array}$ & $\begin{array}{l}\text { Indicating the wish to } \\
\text { speak }\end{array}$ & 0,0 & 0,0 & 4,4 & 4,4 \\
\hline & $\begin{array}{l}\text { Leadership, addressing } \\
\text { someone }\end{array}$ & $\begin{array}{l}\text { Controlling/leading the } \\
\text { course of conversation }\end{array}$ & 0,0 & 0,0 & 6,6 & 8,8 \\
\hline & Total (\%) & & 100,0 & 100,0 & 100,0 & 100,0 \\
\hline
\end{tabular}

As we can see from the table above, in both languages the occurrence of shifts that carry a function of regulating the psychological distance between the speakers is very rare. This is, as we have said above, due to the formal setting of the conversation. On the other hand, in both languages most shifts carry the function of discourse development, however, there were some differences seen in this type of shifts. While there were $28 \%$ of shifts with the function of preserving the basic speech level in Japanese, there were no shifts with this function found in Slovene. The usage of all other shifts with the function of discourse development is very similar in both languages - there is only a noticeable difference seen in the use of shifts with the 
function of indicating a wish to speak, and controlling/leading the conversation. The latter were the shifts conducted by the host in a situation, when speakers were interrupting each other, speaking over each other, or engaged themselves in a rather heated discussion. In order to calm them down, the host intervened. In Japanese there was no such instance, as the conversation was calm and steady throughout the whole show. This is also the reason why there was no instance of a speaker requesting to speak in the Japanese conversation, whereas in the Slovene conversation there were a few instances when speakers asked the host if they could speak. This also shows for a higher level of formality of the Japanese conversation and a slightly more relaxed nature of the Slovene conversation.

\section{Conclusion}

Results of the analysis have shown that the main factor determining the basic speech level of the conversation is the setting of a conversation. Most speakers will use appropriate speech level according to the setting, which in these two conversations was a formal style in Japanese and a formal language in Slovene. However, comparing the two languages from the politeness point of view, we have seen a difference in tendencies of the speech level use.

In order to understand how the relations between the speakers influence linguistic behavior, we have looked at three social factors (social distance (D), relative power (P) and absolute ranking of impositions $(R)$ ) to see what role they might play in linguistic behavior of the speakers. The proper use of speech level is determined according to hierarchical relationship between a speaker and a hearer, content of a conversation, context of a situation, etc. Minami (1987) proposes hierarchy and the level of closeness as the conditions which determine interpersonal relations. The level of closeness may be considered the same as the social distance in the politeness theory, while the hierarchy may be equated with the relative power. Within the three social factors proposed by Brown and Levinson, social distance and absolute ranking of impositions are considered to be fixed in this study, while the relative power differs among the speakers. In other words, as the speakers partake in the same talk show, the conversation content and formality of the situation are fixed (they stay the same throughout the show). However, as we do not have any information about the social distance between the speakers (how well they know each other), we cannot make any judgement on this. Therefore, due to the formal nature of the debate show and considering the attitude and linguistic behavior of the speakers, we may say that the social distance between the speakers is small. Furthermore, because all the speakers are speaking in the same context of situation about the same topic, the ranking of imposition is considered to stay the same throughout the conversation. Because the social distance and ranking of imposition do not change during the conversation, we wanted to see how the relative power (age, social status, etc.) influences the choice of the speech level and speech level shift in both languages. 
We have come to a conclusion that, looking from the politeness theory point of view, there is a difference in the tendency of the use of speech level in both languages.

In Japanese, the informal style (i.e. lower speech level) was used mostly by the speakers who have a higher ranking of power ${ }^{3}$. Whereas in Slovene, speakers with a lower ranking of power were the ones mostly using the lower speech level (i.e. general colloquial language). This shows that the use of speech level in Japanese is influenced by hierarchical relations, whereas the use of speech level in Slovene reflects the speaker's background. Furthermore, we have seen that the Japanese speakers tend to use formal style when expressing their own opinion. By using a formal style a speaker creates certain distance between himself and a hearer, which allows a speaker to freely express their own (opposing) point of view. This corresponds to Brown and Levinson, who say that by using a negative politeness strategy, e.g. using a formal style, a speaker distances himself from a hearer and does not want to invade their private territory.

Moreover, speech level shifts in both languages are essentially not considered to be a deviation from the basic speech level of the conversation, but are rather understood as the means of conducting a smooth conversation.

\section{References}

Brown, P., \& Levinson, S. C. (1987). Politeness: Some universals in language usage. Cambridge: Cambridge University Press.

Matsumoto, Y. (1988). Reexamination of the universality of Face: Politeness phenomena in Japanese. Journal of Pragmatics, 12(4), 403-426.

Matsumoto, Y. (1989). Politeness and conversational universals - observations from Japanese. Multilingua, 9(3), 207-221.

Pizziconi, B. (2003). Re-examining politeness, face and the Japanese language. Journal of Pragmatics, 35, 1471-1506.

Pogorelec, B. (1965). Vprašanje govorjenega jezika (The question of Spoken Language). In Jezikovni pogovori (pp. 132-156). Ljubljana: Cankarjeva založba.

Slovar slovenskega knjižnega jezika (Dictionary of Standard Slovenian) (1994). Ljubljana: DZS.

Tivadar, H. (2003). Podoba in funkcija govorjenega knjižnega jezika glede na neknjižne zvrsti. Obdobja, 22, 437-452.

Toporišič, J. (2000). Slovenska slovnica (Slovene Grammar). Maribor: Založba Obzorje.

Toporišič, J. (1973). Slovenski knjižni jezik 4 (Slovene Literary Language 4). Maribor: Založba Obzorja.

\footnotetext{
${ }^{3}$ To determine the rank of social power among the speakers, we have taken into a consideration their age and profession: the higher the age the higher the ranking of power and speakers with professions for which more education is needed are considered as having a higher ranking of power.
} 
Toporišič, J. et al. (Ed.) (1994). Slovenski pravopis 1, Pravila (Slovene Orthography 1, Rules). Ljubljana: DZS.

Usami, M. (2002). Discourse politeness in Japanese conversation: Some implications for a universal theory of politeness. Tokyo: Hituzi Syobo.

Wardhaugh, R. (1998). An introduction to sociolinguistics. Malden: Blackwell Publishers.

Ikuta S., \& Ide, Y. (1983). Shakai gengogaku ni okeru danwa kenkyū (Discourse research in social linguistics). Gekkan gengo, 12 (12), 77-84.

Usami, M. (1995). Danwa reberu kara mita keigo shiyō: supiichi reberu shifuto seiki no jōken to kinō (Conditions for speech-level shift occurrence in Japanese discourse). Gakuen, 662, 27-42.

Usami, M. (1999). Danwa no teiryōteki bunseki - gengo shakai shinrigakuteki apurōchii (Quantitative discourse analysis - socio-psycholinguistic approach), Nihongogaku, 18 (10), 40-56.

Usami, M. (2001). Disukōsu poraitonesu toiu kanten kara mita keigo shiyō no kinō - keigo shiyō no atarashii toraekata ga poraitonesu no danwa riron ni shisasuru koto (Functions of the use from discourse politeness point of view), Gogaku kenkyūjo ronshū 6.

Usami, M. (Ed.) (2006). Shizen kaiwa bunseki eno gengo shakai shinrigakuteki apurōchii (Socio-psycholinguistic approach for natural conversation analysis). Gengo jōhōgaku kenkyū hōkoku 13.

Usami, M. (2006). Danwa ni okeru rōkaru bunseki to gurōbaru bunseki no igi (The meaning of local and global discourse analysis). Gengo jōhōgaku kenkyū hōkoku 13.

Usami, M. (2011). Kihontekina mojika no gensoku (Rules of basic transcription) (Basic Transcription System for Japanese: BTSJ).

Komiya, S. (1991). Tōronkai bamen no kaiwa sutoratejii (Strategies in debates), Collection of essays on Japanese education of Center for foreign students education of Tsukuba University, 145-165.

Kikuchi, Y. (1997). Keigo. Tokyo: Kōdansha.

Minami, F. (1987). Keigo. Tokyo: Iwanami.

Mimaki, Y. (1993). Danwa no tenkai yōshiki toshite no taigū reberu shifuto (Speech level shift as a mark of a discourse development). Osaka Kyōiku University Repository-Social sciences, 42(1), 39-51.

Mimaki, Y. (2001): Taiwa ni okeru taigū reberu kanri no jisshōteki kenkyū (Empirical study on the management of speech level in conversation). Heisei 9 - Heisei 12, Nendo kagaku kenkyū hojokin kenkyū seika hōkokusho. 